\title{
NMB Gene Product
}

National Cancer Institute

\section{Source}

National Cancer Institute. NMB Gene Product. NCI Thesaurus. Code C139914.

A protein encoded by the NMB gene. 